\title{
Synergic effect of Eicosapentaenoic acid and Lovastatin on gene expression of HMGCoA reductase and $L D L$ receptor in cultured HepG2 cells
}

\author{
Maria Notarnicola*, Caterina Messa, Maria G Refolo, Valeria Tutino, Angelica Miccolis, Maria G Caruso*
}

\begin{abstract}
Background: PUFAs are potent inhibitors of 3-hydroxy-3-methylglutaryl coenzyme A (HMG-CoA) reductase, an enzyme catalyzing the conversion of HMGCoA to mevalonate, the rate limiting step in cholesterol biosynthesis. Statins represent a class of drugs that are widely used to treat hypercholesterolemia for their ability to inhibit cholesterol biosynthesis and to up-regulate the synthesis of Low Density Lipoprotein (LDL) receptors in the liver. PUFAs mediate many, if not all, actions of statins and this could be one mechanism by which they lower cholesterol levels. The purpose of this study was to investigate whether combined treatment with Eicosapentaenoic acid (EPA) and lovastatin enhanced the regulatory effect on gene expression of HMGCoA reductase and LDL receptor in HepG2 cell line.

Results: The combined treatment with EPA and lovastatin enhanced the regulatory effect on gene expression of HMGCoA reductase and LDL receptor in HepG2 cell line. Moreover, we detected a synergistic effect on the inhibition of cancer cell proliferation obtained by combination of EPA and Lovastatin.

Conclusions: The use of EPA, in combination with low doses of Lovastatin may have potential value in treatment of neoplastic diseases.
\end{abstract}

\section{Introduction}

Long-chain polyunsaturated fatty acids (PUFAs), named for the position of their terminal double bond, the $n-6$ and n-3 long-chain PUFAs, are part of the phospholipid structure of all membranes and play additional roles as signaling molecules and modulators of gene expression [1-3]. Long-chain PUFAs may be directly consumed in the diet or synthesized from their essential fatty acid precursors, linoleic acid (LA) and $\alpha$-linolenic acid (LNA) [4].

Clinical studies from cardiovascular medicine, psychiatry and other disciplines have demonstrated correlations between low $n-3$ PUFA levels and increased disease risk $[5,6]$ and have shown that increasing $n-3$ levels by diet or supplementation may confer a variety of health

\footnotetext{
* Correspondence: maria.notarnicola@irccsdebellis.it; gabriella. caruso@irccsdebellis.it

Laboratory of Biochemistry, National Institute for Digestive Diseases Castellana Grotte, Bari, Italy
}

benefits $[1,7,8]$. A major effect of $n-3$ PUFA is to lower plasma triacylglycerols and lipoprotrein concentrations, in normal as well as hypertriglyceridaemic subjects [9].

PUFAs are potent inhibitors of 3-hydroxy-3-methylglutaryl coenzyme A (HMG-CoA) reductase, an enzyme catalyzing the conversion of HMGCoA to mevalonate, the rate limiting step in cholesterol biosynthesis. PUFAs mediate many, if not all, actions of statins [10] and this could be one mechanism by which they lower cholesterol levels.

Statins represent a class of drugs that are widely used to treat hypercholesterolemia for their ability to inhibit cholesterol biosynthesis and to up-regulate the synthesis of Low Density Lipoprotein (LDL) receptors in the liver [11].

Statins having biochemical effects on cholesterol synthesis, are considered as potential anti-tumor agents [12], inhibiting tumor cell growth by restricting either cholesterol availability or cholesterol synthesis $[12,13]$. 
Nevertheless, the use of statins in cancer trials has been greatly limited by their high-dose toxicity that is characterized by severe myopaty [14].

An important feature of malignant transformation is the loss of the cholesterol feedback inhibition mechanism that regulates cholesterol synthesis. The main cholesterol feedback defect in malignant cells has been located at the HMGCoA reductase step.

Cancer cells seem to require an increased concentration of cholesterol and cholesterol precursors and this requirement may be fulfilled by increased HMGCoA reductase activity.

In our previous study, HMGCoA reductase activity was found to be enhanced in human colorectal cancer that did not express LDL receptors [15], indicating that LDL receptors absence, which deprives colonic neoplastic cells of exogenous sterols, is overcome by an increase in endogenous cholesterol synthesis.

Several studies [15-17] have demonstrated that the absence of LDL receptor induces neoplastic cells to depend on endogenous cholesterol synthesis for their proliferation, resulting in an increase of HMGCoA reductase activity inside the cells. Several studies showed that HMGCoA inhibitor blockade of mevalonate synthesis induced cell cycle arrest in vitro [18-20] and inhibited tumor growth in vivo [21].

Previously, we have demonstrated an anti-proliferative effect of simvastatin in two human colon cancer cell lines [16]. Simvastatin inhibited cell proliferation at pharmacological doses in DLD-1 and Caco2 cell lines. The growth inhibition by simvastatin observed in DLD1 cells was mediated by a proapoptotic effect, whereas in Caco2 cells the anti-proliferative effect takes place regardless of apoptosis.

In the present study we investigated in vitro whether combined treatment with Eicosapentaenoic acid (EPA), belonging to omega-3 family, and lovastatin enhanced the regulatory effect on gene expression of HMGCoA reductase and LDL receptor in HepG2 cell line.

\section{Materials and methods}

\section{Cell culture conditions}

HepG2, a cell line derived from human liver tissue with a well differentiated hepatocellular carcinoma, were obtained from the ICLC (IST, Genoa, Italy).

Cells were routinely cultured in DMEM (Dulbecco's modified Eagle's medium) supplemented with 10\% FBS (fetal bovine serum), $100 \mathrm{U} / \mathrm{ml}$ penicillin, $100 \mu \mathrm{g} / \mathrm{ml}$ streptomycin, in monolayer culture, and incubated at $37^{\circ} \mathrm{C}$ in a humidified atmosphere containing $5 \% \mathrm{CO}_{2}$ in air. At confluence, the grown cells were harvested by means of trypsinization and serially subcultured with a 1:4 split ratio. All cell culture components were purchased from Sigma-Aldrich (Milan, Italy).

\section{Lovastatin and EPA treatment}

To elucidate the effect of Lovastatin and EPA on HMGCoA reductase, LDL receptor gene expression and cell proliferation, HepG2 cells were plated at a density of $3 \times 10^{5}$ cells $/ 5 \mathrm{ml}$ of DMEM containing $10 \%$ FBS in 60-mm tissue culture dishes (Corning Costar Co., USA).

Separate plates were seeded for each assay and when the cells were approximately $60 \%$ confluent were exposed to the treatment.

To examine the response to EPA, HepG2 cells were treated for $48 \mathrm{~h}$ with culture medium supplemented with various concentrations of EPA $(1,10,25,50$ and $100 \mu \mathrm{M})$. Each experiment included a control without EPA and a control with the same amount of DMEM -BSA used for dissolving the fatty acid.

To evaluate Lovastatin effect on HepG2 cells, the drug dissolved in $0,1 \mathrm{~N} \mathrm{NaOH}$ was added to the culture medium at increasing concentrations $(1,10,25,50$ and 100 $\mu \mathrm{M})$ and incubated for 48 hours. Each experiment included an untreated control and a control that received the same amount of $\mathrm{NaOH}$ used for adding Lovastatin.

For the experiment testing the effect of combined treatment of Lovastatin and EPA on subconfluent HepG2 cells two sets of experiments were prepared. In the first set, HepG2 cells were incubated with $50 \mu \mathrm{M}$ of EPA and increasing concentrations of Lovastatin $(1,10$, $25,50$ and $100 \mu \mathrm{M})$. The second set of experiments were performed by incubating HepG2 with Lovastatin at the concentration of $50 \mu \mathrm{M}$ with increasing concentrations of EPA $(1,10,25,50$ and $100 \mu \mathrm{M}$ ) (data not shown). In these experimental conditions, HepG2 cells were allowed to growth for $48 \mathrm{~h}$. Each experiment included an untreated control and a control with the equivalent concentration of solvent used for adding Lovastatin and EPA.

Triplicate culture were set up for each compound concentration and for control, and each experiment was repeated 4 times. Cell viability, determined using the trypan blue exclusion test, always exceeded $90 \%$.

\section{LDL receptor and HMG-CoA reductase gene expression}

Analysis of gene expression was performed in HepG2 cells treated with $1,10,25,50$ and $100 \mu \mathrm{M}$ of EPA and Lovastatin alone and with both compounds at established concentrations for 48 hours.

Cells were washed twice in phosphate buffered saline (PBS) and then trypsinized and centrifuged at low speed. The cell pellets were resuspended in $0.3 \mathrm{ml}$ pure distilled water and used for RNA extraction.

Total cell RNA was isolated with TRI-Reagent (Mol. Res. Centre Inc. Cincinnati, USA), following the manufacturer's instruction. Total cell RNA was extracted using Tri-Reagent (Mol. Res. Center Inc., Cincinnati, 
Table 1 Sequences of amplification primers

\begin{tabular}{lll}
\hline Gene & \multicolumn{1}{c}{ Primer } \\
\hline LDL & Sense & 5'-CAATGTCTCACCAAGCTCTG-3' \\
receptor & Antisense & 5'-TCTGTCTCGAGGGGTAGCTG-3' \\
HMG-CoA & Sense & 5'-TACCATGTCAGGGGTACGTC-3' \\
reductase & Antisense & 5'-CAAGCCTAGAGACATAATCATC \\
$\beta$-actin & Sense & 5'-AAAGACCTGTACGCCAACACAGTGCTGTCTGG-3' \\
& Antisense & 5'-CGTCATACTCCTGCTTGCT GATCCACATCTGC-3' \\
\end{tabular}

Ohio, USA), following the manifacture's instruction. About $2 \mu \mathrm{g}$ total cell RNA, extracted from both the control and treated cells, was used for cDNA synthesis. Reverse transcription (RT) was carried out in $20 \mu \mathrm{l}$ of the final volume at $41^{\circ} \mathrm{C}$ for $60 \mathrm{~min}$, using $30 \mathrm{pmol}$ antisense primer (Table 1 ) for analyses of the HMGCoA reductase, LDL receptor and $\beta$-actin gene. The $\beta$-actin gene was utilized as an internal control and was chosen as a reference gene because it is a housekeeping gene.

Real-time PCRs were performed in $25 \mu$ f final volume containing $2 \mu \mathrm{l}$ cDNA, master mix with SYBR Green

$\mathbf{a}$

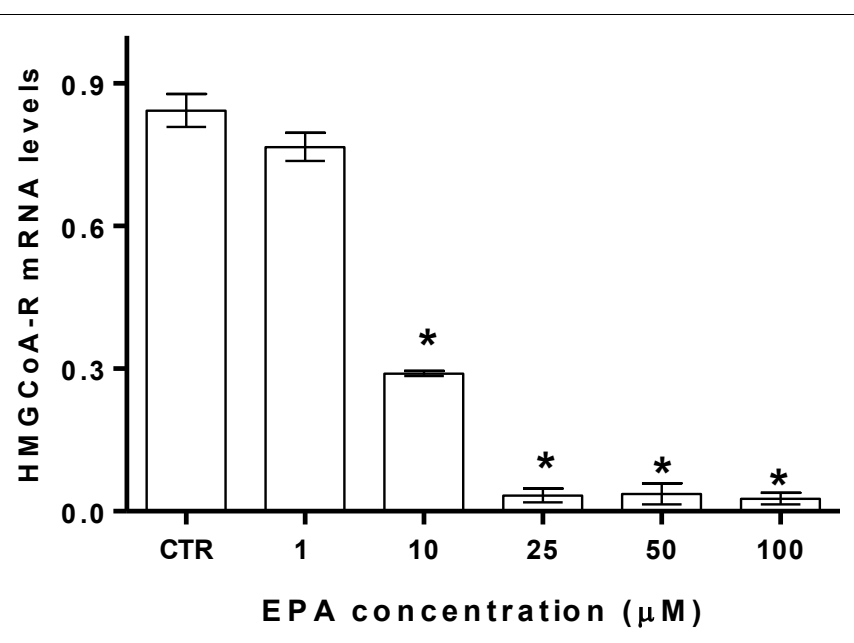

b

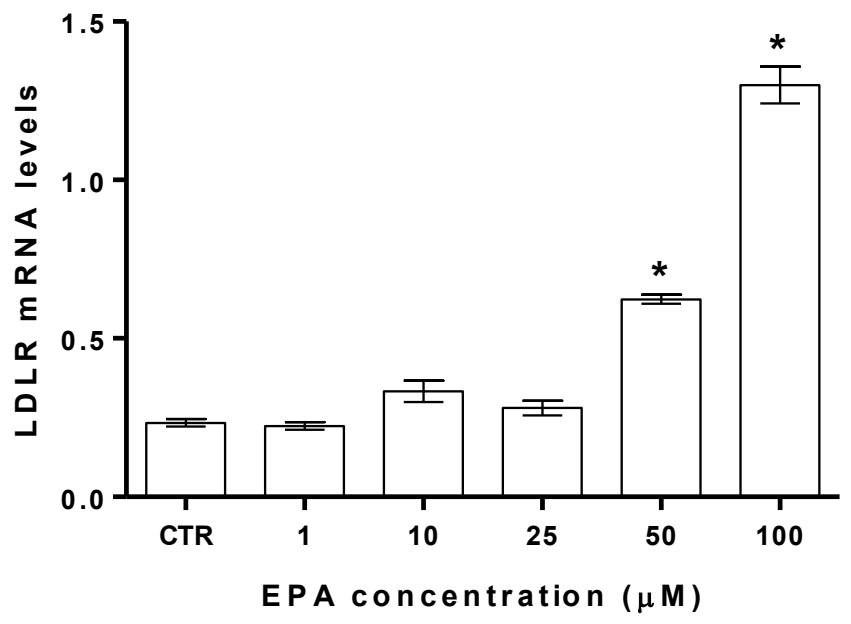

Figure 1 EPA effects on HMGCoA reductase (panel a) and LDLR (panel b) mRNA levels in HepG2 cells. All data represent the mean \pm SE of four consecutive experiments. mRNA levels are expressed as ratio of the amount of gene target by the amount of $\beta$-actin. $P$ value was determined by one way analysis with Dunnett' post test. ${ }^{*} P<0.05$ versus control 
(iQ SYBR Green Supermix; Bio-Rad, Milan, Italy) and sense and antisense primers for HMGCoA reductase, LDL receptor and $\beta$-actin gene (Table 1 ).

Real-Time PCR was carried out with iCycler Thermal Cycler System apparatus (Bio-Rad) using the following parameters: one cycle of $95^{\circ} \mathrm{C}$ for $1 \mathrm{~min}$ and $30 \mathrm{~s}$, followed by 45 cycles at $94^{\circ} \mathrm{C}$ for $10 \mathrm{~s}, 55^{\circ} \mathrm{C}$ for $10 \mathrm{~s}$ and $72^{\circ} \mathrm{C}$ for $30 \mathrm{~s}$ and a further melting curve step at $55-95^{\circ}$ $\mathrm{C}$ with a heating rate of $0.5^{\circ} \mathrm{C}$ per cycle for 80 cycles. The PCR products were quantified by external calibration curves, one for each tested gene, obtained with serial dilution of known copy number of molecules $\left(10^{2}-10^{7}\right.$ molecules). All expression data were normalized by dividing the amount of target by the amount of

a

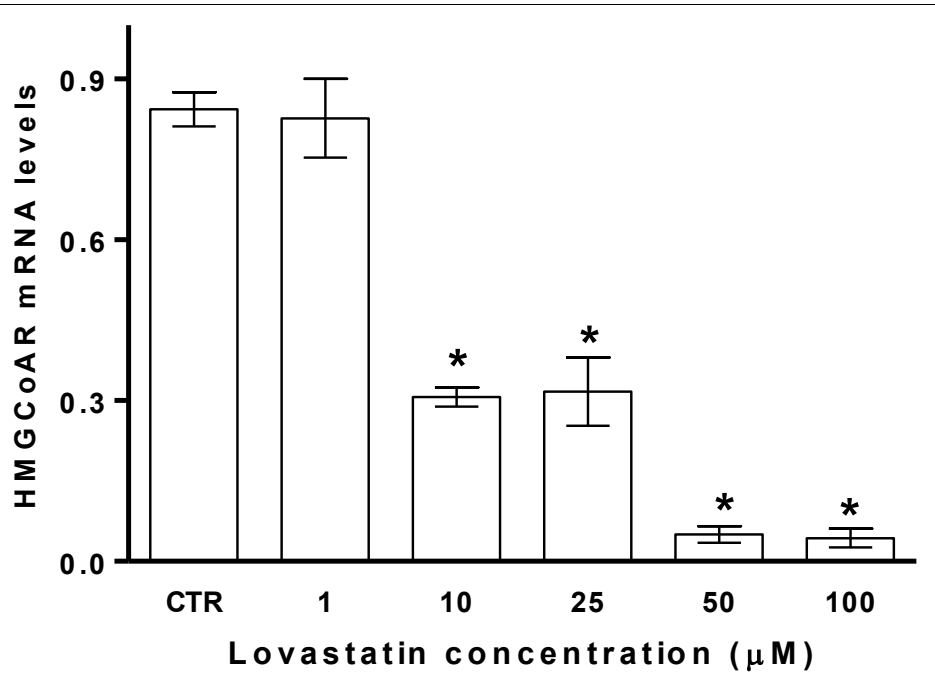

b

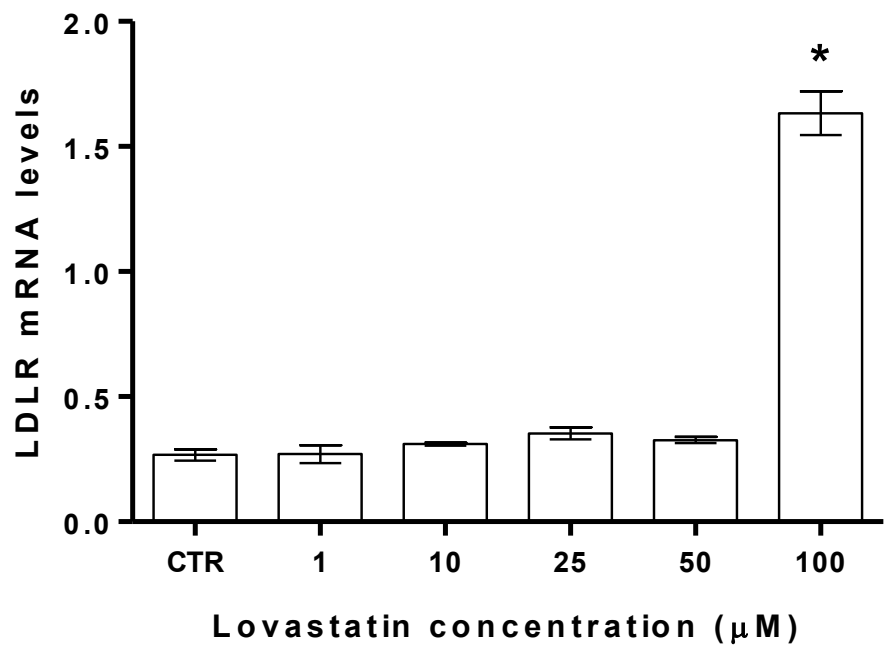

Figure 2 Lovastatin effect on HMGCoA reductase (panel a) and LDLR (panel b) mRNA levels in HepG2 cells. All data represent the mean \pm SE of four consecutive experiments. mRNA levels are expressed as ratio of the amount of gene target by the amount of $\beta$-actin. $P$ value was determined by one way analysis with Dunnett' post test. ${ }^{*} P<0.05$ versus control 
$\beta$-actin used as internal control for each sample. The specificity of the PCR product of each tested gene was confirmed by gel electrophoresis.

\section{Assessment of cell proliferation}

After Lovastatin and/or EPA treatment for 48 hours, the proliferative response was estimated by colorimetric 3 (4,5 di-methylthiazol-2-yl)-2,5-diphenyltetrazolium bromide (MTT) test. In brief, MTT stock $(5 \mathrm{mg} / \mathrm{ml}$ in medium) was added to each dish at a volume of onetenth the original culture volume and incubated for 2 hours at $37^{\circ} \mathrm{C}$ in humidified $\mathrm{CO}_{2}$. At the end of the incubation period, the medium was removed, and blue formazan crystal were solubilized with acidic isopropanol $(0.1 \mathrm{~N} \mathrm{HCl}$ in absolute isopropanol). MTT conversion to formazan by metabolically viable cells was

a

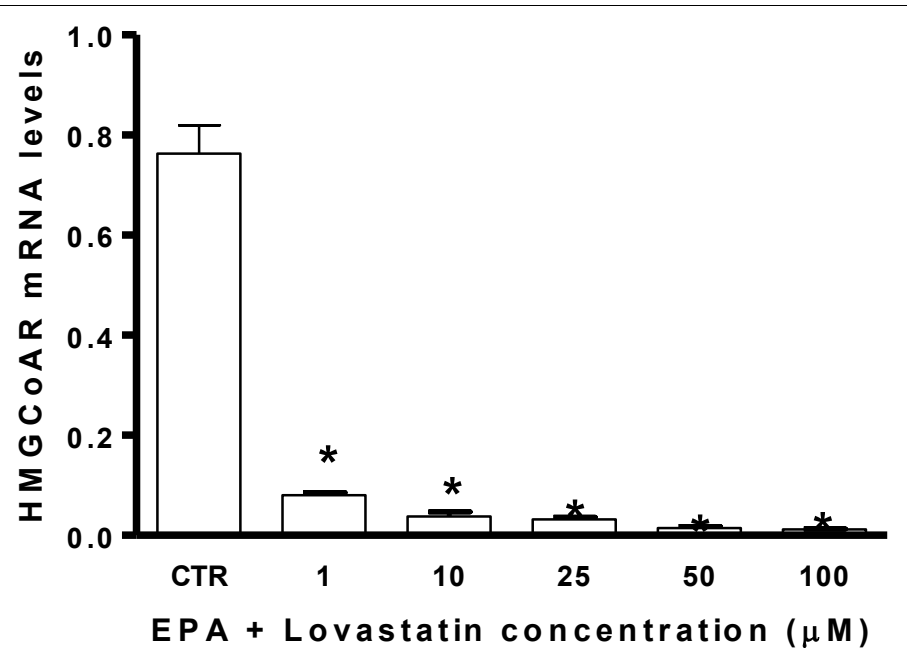

b

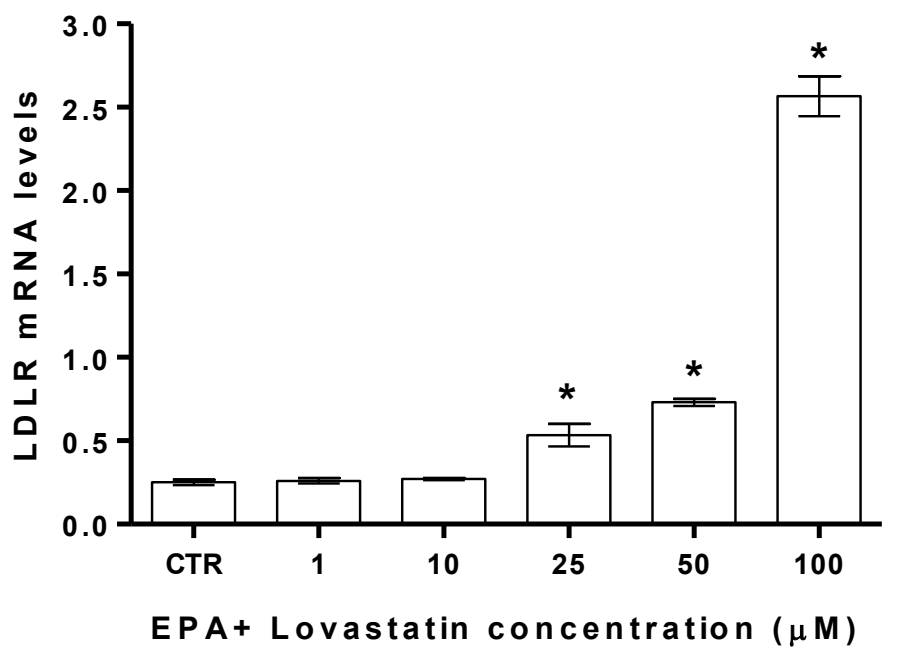

Figure 3 HMGCoA reductase (panel a) and LDLR (panel b) mRNA levels after treatment with $50 \mu \mathrm{M}$ of EPA and increasing concentrations of Lovastatin $(\mathbf{1}, \mathbf{1 0}, \mathbf{2 5}, \mathbf{5 0}$ and $\mathbf{1 0 0} \mu \mathrm{M})$. All data represent the mean \pm SE of four consecutive experiments. mRNA levels are expressed as ratio of the amount of gene target by the amount of $\beta$-actin. $P$ value was determined by one way analysis with Dunnett' post test. ${ }^{*} P<0.05$ versus control. 
monitored by spectrophotometer at an optical density of $570 \mathrm{~nm}$.

\section{Statistical analysis}

The significance of the differences between the control group and each experimental group was evaluated with one way analysis of variance and the Dunnett' post test. Differences were considered significant at a $5 \%$ probability level.

\section{Results}

Results showed that EPA significantly inhibited HMGCoA reductase gene expression and up-regulated mRNA LDL receptor (Figure 1a and $1 \mathrm{~b}$ ).

The treatment of HepG2 cells with increasing concentrations of Lovastatin caused a similar effect to that induced by EPA (Figure 2a and $2 \mathrm{~b}$ ). The regulatory effect on LDLR receptor gene expression was significantly evident at higher concentrations (Figure 2b).

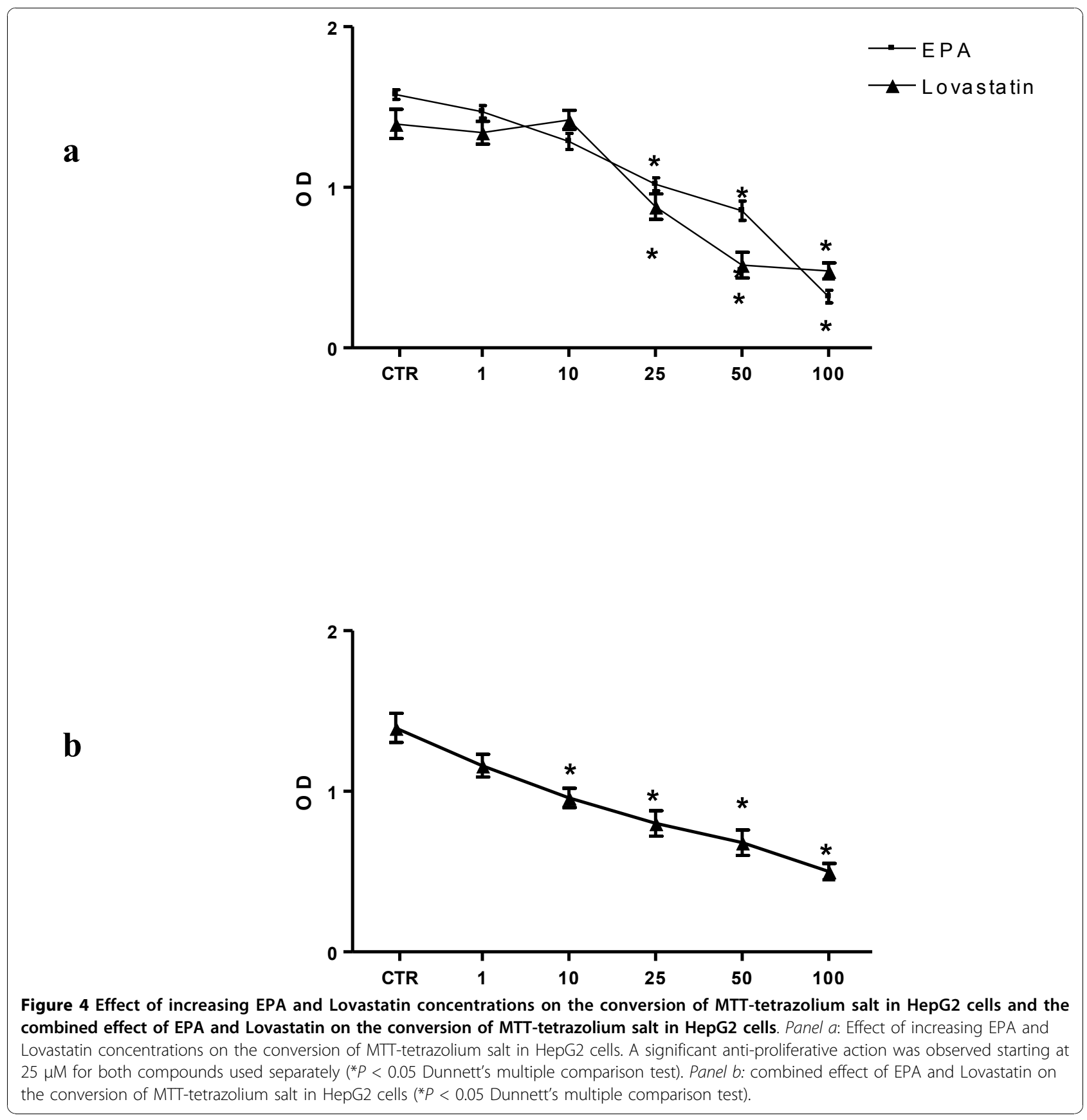


By the combination of both compounds, the effects on regulation of expression of both genes were detected at lower doses (Figure 3a and 3b).

In addition, EPA and Lovastatin, used separately, elicited a significant anti-proliferative effect in HepG2 cells starting at concentration of $25 \mu \mathrm{M}$ (Figure 4a). The inhibition of cell proliferation was obtained at lower doses after combined treatment of EPA and Lovastatin (Figure 4b).

Cell growth inhibitory effect and gene regulation were similar using fixed EPA or Lovastatin, indifferently.

\section{Discussion}

The anti-proliferative activity of EPA and statins has been suggested by numerous studies showing efficacy in smooth muscle, glioma, colon, ovarian and hepatoma cells [16,22-26].

In this study, we demonstrate the efficacy of EPA in regulation of lipid metabolism, as well as we confirm its anti-proliferative effects. Analysis of gene expression revealed in HepG2 cells an inhibition of HMGCoA reductase mRNA levels accompanied with an up-regulation of LDLR gene expression after EPA treatment. These effects, on both genes tested, were similar to those observed after Lovastatin exposure.

The combined treatment with EPA and lovastatin enhanced the regulatory effect on gene expression of HMGCoA reductase and LDL receptor in HepG2 cell line. Moreover, we detected a synergistic effect in the inhibition of cancer cell proliferation obtained by combination of EPA and Lovastatin.

The efficacy in regulation of gene expression and cell proliferation inhibition was detected at the lower doses with respect to the substances used separately. Furthermore, this synergistic effect of combined treatment was found to be not cytotoxic.

Previous studies have revealed that PUFA can regulate the expression of genes involved in several metabolic pathways [9,27]. Fish oil feeding, rich in the $n-3$ PUFA, drastically decreased mRNA levels for lipogenic enzymes in rodent liver [28]. PUFAs may control cholesterogenic gene expression through their effects on SREBP- dependent regulation [9]. SREBP-responsive genes include those coding for HMGCoA reductase and for intermediates in cholesterol synthesis, as Farnesyl Pirophosphate Synthase (FPPS). PUFAs decreased mRNA levels of lipogenic enzymes in rat hepatoma cells and mouse liver, in correlation with their effects on HMGCoA reductase [9].

The use of statins as monotherapy in the prevention or treatment of cancer has been limited in order to avoid potential detrimental effects that would have a negative impact on the health and well-being of the patient.
In order to avoid unwanted adverse side effects associated with high doses of statins, several studies have taken the approach to combine low doses of statins with other anticancer agents [29,30]. Experimental evidences suggest that statins and PUFAs have a reciprocal influence and the combined use of two compounds seems to have health beneficial effects $[1,24]$.

The present work demonstrates that an additional advantage of synergistic effect could be the possible reduction of the doses of statin, thus limiting toxicity.

In conclusion, the pharmacological modulation of PUFAs combined with low doses of statins, even if merits further investigations in both preclinical and clinical settings, could be considered favorable in treatment of neoplastic diseases.

\section{Authors' contributions}

MN and MGC conceived the study, participated in its design and coordination; CM, MGR, VT, and AM, performed various experiments; $M N$ and MGC interpreted the data and wrote the manuscript; all authors read and approved the final manuscript.

\section{Competing interests}

The authors declare that they have no competing interests.

Received: 22 October 2010 Accepted: 30 November 2010 Published: 30 November 2010

\section{References}

1. Harris Jl, Hibbeln JR, Mackey RH, Muldoon MF: Statin treatment alters serum n-3 and n-6 fatty acids in hypercholesterolemic patients. Prost Leuk and Essen Fatty Acids 2004, 71:263-269.

2. Kitajka K, Puskas LG, Zvara A, Hackler L Jr, Barceló-Coblijn G, Yeo YK, Farkas T: The role of $n-3$ polynsaturated fatty acids in brain: modulation of rat brain gene expression by dietary $n-3$ fatty acids. Proc Natl Acad Sci USA 2002, 99:2619-2624.

3. Barcelo-Coblijng G, Kitajka K, Puskas LG, Hogyes E, Zvara A, Hackler L Jr, Farkas T: Gene expression and molecular composition of phospholipids in rat brain in relation to dietary $n-6$ to $n-3$ fatty acid. Biochim Biophys Acta-Mol Cell Biol Lipids 2003, 1632:72-79.

4. Pawlosky RJ, Hibbeln JR, Lin Y, Goodson S, Riggs P, Sebring N, Brown GL, Salem N Jr: Effects of beef- and fish -based diets on the kinetics of n-3 fatty acid metabolism in human subjects. Am J Clin Nutr 2003, 77:565-572.

5. Harper $C R$, Jacobson TA: The fats of life- the role of omega- 3 fatty acids in the prevention of coronary heart disease. Arch Int Med 2001, 161:2185-2192.

6. Kris-Etherton PM, Harris WS, Appel LJ: Fish consumption. Fish oil, omega-3 fatty acids and cardiovascular disease. Circulation 2002, 106:2747-2757.

7. Whelan J: Antagonistic effects of dietary arachidonic acid and n-3 polynsaturated fatty acids. J Nutr 1996, 126:S1086-S1091.

8. Rubin D, Laposata M: Cellular interaction between $n-6$ and $n-3$ fatty acids: a mass analysis of fatty acid elongation/desaturation, distribution among complex lipids and conversion to eicosanoids. J Lipid Res 1992, 33:1431-1438.

9. Le Jossic-Corcos C, Gonthier C, Zaghini I, Logette E, Shechter I, Bournot P: Hepatic farnesyl diphosphate synthase expression is suppressed by polyunsaturated fatty acids. Biochem J 2005, 385:787-794.

10. Das UN: Essential fatty acids as possible mediators of the actions of statins. Prost Leuk and Essen Fatty Acids 2001, 65:37-40.

11. El Serag HB, Johnson ML, Hachem C, Morgan RO: Statins are associated with a reduced risk of hepatocellular carcinoma in a large cohort of patients with diabetes. Gastroenterology 2009, 136:1601-1608.

12. Shibata MA, Kavanaugh C, Shibata E, Abe H, Nguyen P, Otsuki Y, Trepel JB, Green JE: Comparative effects of lovastatin on mammary and prostate 
oncogenesis in transgenic mouse models. Carcinogenesis 2003, 24:453-459.

13. Wong WW, Dimitroulakos J, Minden MD, Penn LZ: HMGCoA reductase inhibitors and the malignant cell: the statin family of drugs as triggers of tumor-specific apoptosis. Leukemia 2002, 16:508-519.

14. Thibault A, Samid D, Tompkins AC, Figg WD, Cooper MR, Hohl RJ, Trepel J, Liang B, Patronas N, Venzon DJ, Reed E, Myers CE: Phase I study of lovastatin, an inhibitor of the mevalonate pathway, in patients with cancer. Clin Cancer Res 1996, 2:483-491.

15. Caruso MG, Notarnicola M, Santilo MR, Cavallini A, Di Leo A: Enhanced 3Hydroxy-3-Methyl-Glutaryl Coenzyme A Reductase activity in human colorectal cancer not expressing low density lipoprotein receptor. Anticancer Research 1999, 19:451-454.

16. Notarnicola M, Messa C, Pricci M, Guerra V, Altomare DF, Montemurro S, Caruso MG: Up-regulation of 3-hydroxy-3-methylglutaryl coenzyme A reductase activity in left-sided human colon cancer. Anticancer Res 2004, 24:3837-3842.

17. Bennis F, Favre G, Le Gallard F, Soula G: Importance of mevalonatederived products in the control of HMGCoA reductase activity and growth of human lung adenocarcinoma cell line A549. Int I Cancer 1993, 55:640-645.

18. Fairbanks KP, Witte LD, Goodman DS: Relationship between mevalonate and mitogenesis in human fibroblasts stimulated with platelet-derived growth factor. J Biol Chem 1984, 259:1546-1551.

19. Kanedo I, Hazama-Shimada Y, Endo A: Inhibitory effects on lipid metabolism in cultured cells of ML-236B, a potent inhibitor of 3hydroxy-3-methylglutaryl-coenzyme-A reductase. Eur J Biochem 1978, 87:313-321.

20. Quesney-Huneeus V, Galick HA, Siperstein MD, Erickson SK, Spencer TA, Nelson JA: The dual role of mevalonate in the cell cycle. J Biol Chem 1983, 258:378-385.

21. Maltese WA, Defendini R, Green RA, Sheridan KM, Donley DK: Suppression of murine neuroblastoma growth in vivo by mevinolin, a competitive inhibitor of 3-hydroxy-3-methylglutaryl-coenzyme-A reductase. J Clin Invest 1985, 76:1748-1754.

22. Ogunwobi OO, Beales IL: Statins inhibit proliferation and induce apoptosis in Barrett's esophageal adenocarcinoma cells. Am J Gastroenterol 2008, 103:825-837.

23. Ali H, Shirode AB, Sylvester PW, Nazzali S: Preparation, characterization, and anticancer effects of simvastatin-tocotrienol lipid nanoparticles. Int $J$ Pharm 2010, 389:223-231.

24. Wali VB, Sylvester PW: Synergistic antiproliferative effects of $\gamma$-tocotrienol and statin treatment on mammary tumor cells. Lipids 2007, 42:1113-1123.

25. Trombetta A, Maggiora M, Martinasso G, Cotogni P, Canuto RA, Muzio G: Arachidonic and docosahexaenoic acids reduce the growth of A549 human lung-tumor cells increasing lipid peroxidation and PPARs. Chemico-Biological Interactions 2007, 165:239-250.

26. De la Torre A, Debiton E, Durand D, Chardigny JM, Berdeaux O, Loreau O, Barthomeuf C, Bauchart D, Gruffat D: Conjugated linoleic acid isomers and their conjugated derivatives inhibit growth of human cancer cell lines. Anticancer Res 2005, 25:3943-3949.

27. Risè P, Marangoni F, Galli C: Regulation of PUFA metabolism: pharmacological and toxicological aspects. Prost Leuk and Essen Fatty Acids 2002, 67:85-89.

28. Choi YS, Goto S, Ikeda I, Sugano M: Effect of dietary n-3 polynsaturated fatty acids on cholesterol synthesis and degradation in rats of different ages. Lipids 1989, 24:45-50.

29. Duncan RE, El-Sohemy R, Archer MC: Regulation of HMG-CoA reductase in MCF-7 cells by genistein, EPA and DHA, alone and in combination with mevastatin. Cancer Lett 2005, 224:221-228.

30. McAnally JA, Gupta J, Sodhani S, Bravo L, Mo H: Tocotrienols potentiate lovastatin-mediated growth suppression in vitro and in vivo. Exp Biol Med (Maywood) 2007, 232:523-531.

doi:10.1186/1476-511X-9-135

Cite this article as: Notarnicola et al: Synergic effect of Eicosapentaenoic acid and Lovastatin on gene expression of HMGCoA reductase and LDL receptor in cultured HepG2 cells. Lipids in Health and Disease 2010 9:135.

\section{Submit your next manuscript to BioMed Central and take full advantage of:}

- Convenient online submission

- Thorough peer review

- No space constraints or color figure charges

- Immediate publication on acceptance

- Inclusion in PubMed, CAS, Scopus and Google Scholar

- Research which is freely available for redistribution 